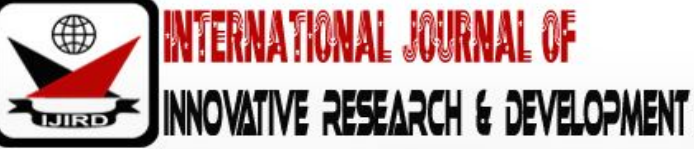

ISSN 2278 - 0211 (Online)

\section{An Investigation into the Potential of Paper and Cardboard Products as Alternative Building Materials in Uganda`S Building Industry}

Albert Wasswa Shinnosuke
Graduate Architect, Department of Architecture \& Physical planning, School of Built Environment,
College of Engineering, Design, Art and Technology, Makerere University, Kampala, Uganda
Kenneth Ssemwogerere
Practicing Architect, Department of Architecture \& Physical planning, School of Built Environment,
College of Engineering, Design, Art and Technology, Makerere University, Kampala, Uganda

\begin{abstract}
:
From ancient times, paper has served as a material to write on. Through paper, messages were exchanged, history was recorded and commodities were wrapped. Paper and its derivative forms have hardly been explored as a building material in Uganda despite their availability and affordability. This can be attributed to the wide spread ignorance and indifference to the concept of recycling and re-use in Uganda. The aim of this study was to examine the potential of paper and cardboard products as building materials in the context of Uganda 's building industry. The research methods that were employed in this study included Observation, Photography, sketches, face to face interviews and literature review. In general, the research was found that paper-based materials have not widely been used in Uganda, their application being mainly as wall finishes. A review of the case studies disclosed that the array of paper-based materials has been used in the construction of structures, both temporary and permanent including emergency housing, primary school buildings, bridges and pavilions among others, as well as in product and interior design. In general, the recommended uses of the materials are based on their unique material characteristics, particularly low cost, recyclability and short life span. The applications comprise structures both temporary and permanent structures, as well as a number of building components such as temporary retail structures, temporary event structures, housing and other permanent low-rise buildings.
\end{abstract}

Keywords: Paper, cardboard, building materials, Uganda

\section{Introduction}

From ancient times, paper has served as a material to write on. Through paper, messages were exchanged, history was recorded and commodities were wrapped. The culture of writing on paper continues to date and paper is undisputed in this field while its younger siblings, notably cardboard and paperboard are widely used as packaging materials.

Historically, the use of paper in Architecture was explored to a large extent in Japan where paper door paneling and wall paper finish were common features of the traditional Japanese house, perhaps due to the presence of dense forests which readily availed wood and of course paper. In recent times, the use of paper in Architecture is slowly picking on with architects like Shigeru Ban and Mick Eekhout leading the way in the development of new technologies in paper architecture. Shigeru Ban, for instance, has used paper tubes in the construction of temporary housing, pavilions, theatres, schools and bridges, most of which are humanitarian works and have therefore made enormous contributions to communities in need.

In Uganda, the wide use of paper as a writing and packaging material, coupled with its temporary nature have immensely contributed to the notion that paper or its derivative forms cannot be used in the building industry. In addition, the widespread ignorance and indifference to the use of recycled paper have led to the continued wastage of used paper. This presents an opportunity for the possible use of waste paper as a building material that may provide efficient and affordable alternatives to the commonly used materials.

\subsection{Objectives}

The aim of this study was to examine the potential of paper and cardboard products as building materials. In detail the study sought to: investigate the extent to which paper and cardboard products have been used in Uganda`s building industry; analyze the extent to which paper and cardboard products have been used as building materials outside Uganda; examine the potential of paper and cardboard products as building materials in Uganda's building industry; recommend possible applications of paper and cardboard products, specific to Uganda`s building industry. 


\section{Methodology}

The methods of data collection employed in this study included; Observation - the researcher used his naked eyes to obtain data on how paper was being used as a building material in Kampala, providing first-hand information that could not be obtained through photographs or sketches done by other persons; Photography - involved the use of a camera to capture photographs of what had been observed through the researcher's eyes. These photographs enabled further analysis of data and were also in documentation to provide a glimpse of what the researcher actually saw to readers; Sketches - These were to be hand-drawn in a sketchbook and were used to record data in situations where photography was difficult or could not be used; Face to face interviews- These were in form of face to face meetings with resource persons such as architects, building material retailers and researchers.

\subsection{Paper and Board}

Holik (2006) defines paper as a thin layer of mostly cellulosic plant fibres, produced on a screen by dewatering a slurry of fibres in water. The slurry is called pulp. Despite recent developments such as proteinic or synthetic fibres, chemical additives, coating and so on, the "cellulosic plant fibre" will be the main component of paper and water will be used in preparing the pulp and in forming the paper web also in the future. A paper structure as bounded by its surfaces is composed of fibres and voids between fibres. The extent of entanglement of the fibres into a matrix depends on the dimensions of the fibre, shape of the fibre, its surface area relative to its mass, its flexibility and other factors. A sheet of paper then exhibits the properties of a structure by virtue of the fibre elements being locked in their relative positions, by felting from a water suspension and finally by being bonded when dried with or without addition of auxiliary bonding agents. Although a sheet of paper can be made merely by felting, its properties would not render it generally useful because of its flimsiness. This deficiency is overcome by bonding fibre to fibre either mechanically or by adding binding materials such as starch, protein, latex and similar adhesive materials.

\subsection{Types of Paper and Board}

Holik (2006) states that there are approximately 3000 kinds of paper and board products. Most products with a basis weight up to $225 \mathrm{~g} \mathrm{~m}^{2}$ are defined as paper and those above $225 \mathrm{~g} \mathrm{~m}^{2}$ are called board, although the naming overlaps. Depending on their use, the paper and board grades are divided into four main groups as follows;Graphic papers: This refers to a large range of papers which are suitable for writing and printing. They are made from virgin or recycled fibres or a mixture of them. Graphic papers are divided into printing and press papers and office and administration papers.

Packaging paper and board grades: A large number of paper and board grades are available for packaging and are employed for many different purposes. Packaging paper grades range from simple wrapping paper to kraft paper and are predominantly supplied in rolls. These grades are employed in the production of bags, beer mats, carrier bags and gift wrapping paper among others. Packaging paperboard grades can be classified into three categories i.e. carton-boards, container-boards and specialty boards.

Hygienic papers: The major component of all hygienic papers is tissue. Tissue describes all products made from lightweight creped papers such as toilet paper, kitchen towels, handkerchiefs, facials, napkins, hand towels and wipes. Hygienic papers can be divided into cellulose wadding, tissue and crepe paper.

Specialty paper and board grades: This group of paper and board covers a wide range of grades. The most important sub-groups comprise base papers for décor, priming and barrier foils, coating and soakage, wall paper, electrotechnical purposes, drawing paper, photographic base paper and cigarette paper among others. They also include base papers for special cardboards for various sectors of the industry such as pressboard, car body and shoe cardboard. All these papers and boards have a common requirement; they must exactly fulfil defined quality criteria according to the use.

Lyons (2012) states that in the recycling process, waste paper and cardboard are broken down and converted to pulp, which is a suspension of cellulose fibres in water. The pulp flows onto a conveyor belt, where it is drained of the excess water and compressed, causing the fibres to felt together producing a long roll of paper. Flat cardboard sheets are formed by gluing together successive layers of paper. Tubes are manufactured from multiple layers of spirally wound paper piles, starting on a steel tube former of the appropriate size, the adhesive being starch or PVA glue. The first and last layers of paper can be of a different quality, for example, impregnated or coloured to create the required surface finish.

\subsection{Recycling of Paper in Uganda}

Recycling of paper is a new concept in Uganda. According to Kezaabu (2010), Makerere was to start burning examination scripts in 2006 due to lack of storage facilities. Godfrey Atuheire Korinako, a student of the university at the time, took it on as a dissertation topic and found that there are tens of thousands of tons of waste paper burnt into ashes every year. He also discovered that all the abandoned waste paper could be used to make paper and paper products. He found that there was no written information in Uganda about the topic and therefore relied on foreign sources.

Radcliffe (2012) posits that there is a huge demand for all kinds of used paper in Kampala. Potential recipients of used paper are discussed below by the type of paper they need.

Stationery: White computer paper is used to make recycled paper products by various companies including PaperCraft. PaperCraft used to have a relationship with one of the major banks in Kampala that met a large portion of its paper needs but unfortunately that partnership is no longer in place. The company now buys used paper on the local market, which is a big expense and it also welcomes donations. Global Paper Products in Kampala also collects used stationery to produce luxury toilet paper, serviettes and facial tissues. The company buys cardboard that is transformed into toilet paper rolls. 
Magazines: There are a million and one groups around Kampala that use magazines and calendars to make paper bead jewellery. A renowned example is Beadforlife, a non-governmental organisation.

Newspapers: The Uganda Society for the Protection and Care of Animals (USPCA) is always in dire need of newspapers which it uses to protect its floor from dog urine and faeces in the animal shelters.

\subsection{Properties of Paper as a Building Material}

According to Gribbon and Foerster (2008), each material has its own unique characteristics which generate specific applications in the building industry. In this light, Preston and Banks (2011) argues that paper can be used in ways that take advantage of its material properties, recyclability and low cost. Miyake (2009) mentions that Shigeru Ban, for instance, regards the paper tube as being on the order of 'higher developed' species of wood and anticipates a new diversity of spaces that will capitalise on its distinct characteristics.

The various qualities of paper and paper-based materials that determine their use in the building industry are stated as follows. Low cost: Paper-based materials are generally inexpensive and easy to source as posited by Eekhout (2008). He adds that the opportunities for cardboard are largely influenced by its low unit price and inferior quality yet numerous technical potential improvements. Recyclable: Eekhout (2008) states that derivative forms of paper have potential for application in many architectural fields because they are recyclable, bio-degradable and made from renewable resources. Cardboard, for example, on top of being cheap, consists of $90 \%$ endlessly recycled material and following use, can be recycled to a degree of 90\%. Light weight: Eekhout (2008) explains that paper-based materials are remarkably strong considering their light weight. He adds the lightness and portability of these materials are properties fitting its short life span and temporary applications. In addition to its light weight, the ability to fold and slide have led to a number of designs for temporary housing.

Durability: Another property of paper worth noting is its proneness to damage by elements of weather. As posited by Preston and Banks (2011), paper tubes require protection from the sun's UV rays, rain and other elements but the top priority should be given to keeping the tubes dry given their sensitivity to changes in moisture content. Paper-based materials need to be treated in order to protect them from the elements and therefore make them more durable. Variety of forms: Paper-based materials come in a number of forms ranging from tubes to panels. Paper tubes, for instance, offer a variety of circumferences, thicknesses and lengths for one to choose from. Miyake (2009) mentions that the flexibility of arrangement of the tubes also makes it possible to sculpt a space with concave or convex characteristics.

\subsection{Properties of Cardboard as a Building Material}

Lyons (2007) posits that cardboard, like timber, is combustible and can be treated to improve its fire performance, particularly in relation to the surface spread of flame test. However, some fire-retardant materials are environmentally unfriendly and should be avoided if the cardboard is to be subsequently recycled.

The structural strength of cardboard is seriously affected by water. Cardboard, even if specially treated in its manufacture, is a hygroscopic material which will readily absorb moisture. It is therefore necessary to protect it from warm moist air within the building using an impermeable membrane, and externally from rain using a breathing membrane, the latter preventing the build-up of interstitial moisture.

Cardboard is potentially vulnerable to rot and insect attack. This could be prevented by treatment with boron products. However, this would adversely affect the potential for ultimate recycling of the cardboard. As cardboard is a recycled material, it has a low embodied energy and can legitimately be considered green.

\subsection{Architectural Applications of Paper}

According to Van Dooren and Verheijen (2008), the applications of paper in architecture can be classified into its use in the design of architectural structures/ projects and architectural products. Generally, paper can be used in the construction of both permanent and temporary structures as posited by Preston and Banks (2011), for example, they state that paper tubes have been used in column, beam and shell-type configurations for both temporary and permanent structures.Similarly, Miyake (2009) mentions that through Shigeru Ban`s first public use of the paper tube wall and ceiling structures, he realised that paper tubes could be used to form interiors and exteriors of buildings, or even constitute a buildings entire structure.

In the interior design field, paper has been used to design interior elements such as interior walls, shelves, worktops, lamp holders, doors, ceiling boards and at times ceilings, according to Van Dooren and Verheijen (2008). They give the example of an entire office interior in Eindhoven that was designed by Ro Koster and Ad Kil, Ro\&Ad, using corrugated cardboard.

Paper has been used in the design of various architectural products ranging from wall paper, wall partitions and ventilation ducts to furniture. Wall paper: A very well-known and traditional application of paper in the building industry, according to Eekhout (2008), is wall paper. It is known to offer a variety of colours, patterns and textures that enhance the aesthetic effects of interiors. In addition, it has quite a number of performance benefits such as ease of application, durability, fire resistance, as well as recyclability.

Walls and partitions: The idea of using cardboard for internal walls is attributed to the very short lifespan of dividing walls in office buildings, as companies are continuously moving, merging or going bankrupt. The cardboard interior wall takes advantage of the re-usability, lightweight and high strength properties of honeycell board, as posited by Van Dooren and Verheijen (2008). Miyake (2009) mentions that Shigeru Ban Laboratory came up with the Paper Partition System (PPS) which has been used to provide privacy to the 2005 Kobe earthquake victims, who had been evacuated to a school gymnasium. The system was composed of columns and beams made entirely with paper tubes. The walls were thin 
sheets of PVC that were stretched over the tubes. The partition was a very simple one and could be built by anyone in half an hour.

In general, literature concerning the use of recycled paper in Uganda shows that its use in the building industry is yet to be explored. This research will therefore contribute new knowledge to a field that has not been previously been ventured into.

\section{Analysis of the Findings}

\subsection{The Use of Paper-Based Materials in Uganda `S Building Industry}

The research revealed that the paper-based materials in use in Uganda`s building industry were wall paper, soft board and cardboard. The use of the materials had been geared mainly by architects, who selected the materials for knowledge of their technical merits, and by some building owners, who simply improvised the materials without much technical knowledge. Architects chose wall paper over the conventional wall finishes in some of their projects because of characteristics unique to it especially the ability to be printed on, its easy and quick application, low cost, as well as flexibility. The fact that wall paper accepts accurate digital printing has enabled architects to explore a variety of wall designs, patterns and textures to create unique aesthetics in office, restaurant and hotel interiors.

Soft board was also widely used on walls as notice/ display boards in offices and educational institutions because of its durability, light weight and the fact that papers and flyers can easily be pinned on it. In addition, soft board has served as a wall finish in music recording studios because of its good acoustics and as a low cost alternative material for ceilings in low end residences. Cardboard has been improvised as a walling material in the structures owned by low income earners, who have taken advantage of its availability since there is no apparent use for discarded cardboard. It is therefore easier to source as compared to other wall finishes such as plaster and paint, which in most cases cannot be afforded by such people.

Unfortunately, the use of paper-based materials in Uganda `s building industry was not extensive mainly due to the widespread ignorance and disinterest of the architects, clients, material retailers and the general public, coupled with the poor attitudes towards these materials.

The challenges faced in the use of paper-based materials in Uganda`s building industry can be attributed to the deficiencies of its material properties especially the fact that it is combustible and prone to damage by the elements of weather. Some of the challenges of using paper products in the building industry included: Building regulations - Miyake (2009) talks of the difficulty that Shigeru Ban faced in having his Hannover pavilion project approved by local authorities in Germany. This was because of the strict building regulations that required a standard level of fire-retardance which the paper tubes used in the structure could not meet. Similarly in Uganda, building regulations, although not so specific, do not favour the use of paper-based materials. For example, the Public Health Act (1951) Section 79 states that all walls of public buildings shall be made entirely or partly of brick, stone, concrete or other fire-proof construction to the satisfaction of the local authority. The floors and ceilings of all passages, corridors, vestibules, stairs and staircases are also required to be constructed of concrete or other approved fireproof construction.

Weather elements- Elements specifically rain has long been an obstacle to the use of paper-based materials in buildings but it has been overcome through the technological developments over the years. According to Van Dooren and Verheijen (2008), paper-derived materials have often been treated with various compounds such as polythene in order to protect them from the elements of weather.

Proneness to damage by fire and water; Paper-based materials are all liable to damage when exposed to fire and water. Buildings made of these materials are vulnerable to fire risks because paper is highly combustible. In addition, paper readily absorbs moisture upon which it loses its form and strength. Fortunately, the materials can be protected from fire and water using various treatments but extra precautions should be taken in selecting paper-based materials. Short lifespan - Paper structures have short life spans as dictated by the nature of their parent paper. This property substantially reduces the range of possible applications of paper-based materials in Uganda `s building industry.

Poor public attitudes - The phenomenon of the use of paper-based materials in buildings is either new or not known to the general public in Uganda. Clients and architects are also indifferent about the use of such materials in their projects unlike in countries overseas. Cost of collecting paper- Collection of raw material waste paper for the production of paper-based materials may prove costly as there is no proper collection system in place. It will require individuals or organizations to search for sources of waste paper.

\section{Conclusion}

The field survey revealed that paper-based materials particularly wall paper, soft board and cardboard had been used in a few instances. Wall paper has been used for walling in offices, hotels, restaurants and residences, soft board for walling in recording and architectural studios, and cardboard for walling in low-end structures.

In general, it was found that paper-based materials have not widely been used in Uganda, their application being mainly as wall finishes. This was attributed to the widespread ignorance and scarcity of the materials as the only ones available on the market were wall paper and softboard. Other forms of paper for building such as honeycomb panels and paper tubes among others were not available and were therefore yet to be explored in the building industry.

In addition to the applications already existing in Uganda, paper based materials can further be used in various architectural projects such as pavilions, temporary housing, bridges, interior and product design as exemplified by the international case studies. The successful use of the materials in building projects overseas and lack of exploration in local projects present a range of opportunities for their use in Uganda`s building industry. 
American Society for Testing and Materials, (1963), Paper and paperboard: Characteristics, nomenclature and significance of tests, $3^{\text {rd }}$ edition, Baltimore: American society for testing and materials.

\section{References}

i. Berger. S. H, (1968), Ostafrikanische Studien. Nürnberg: Herausgegeben im Selbstverlagdes Wirtschafts-und Sozialgeographischen Instuts der Friedrich-Alexander-Universitat.

ii. Bernd. H, (1984), In a patch of fireweed, Harvard University press, Cambridge, Massachusetts and London.

iii. Buck. D.N, (2001), Responding to Chaos: Society, Tradition, Technology \& Order in Japanese Design, London: Spon press.

iv. Cripps. A, (2007), Cardboard as a construction material: A case study, London: Taylor and Francis,

v. De Vaus, D.A, (2001), Research design in social research, London: Sage publications.

vi. Denzin. N.K, Lincoln.Y.S, (1994), Handbook of qualitative research, Thousand Oaks, California:

vii. Sage publications.

viii. Denzin. N.K, Lincoln.Y.S, (2000), Handbook of qualitative research, 2nd Edition, Thousand Oaks, California: Sage publications.

ix. Eekhout. M, (2008), Cardboard in Architecture, Amsterdam, IOS press.

x. Foerster. F, Gribbon. H, (2008), Structural engineering and design in paper and cardboard, Amsterdam, IOS press.

xi. Government of Uganda, (1951), The Public Health Act: Statutory instrument 281-1, Government of Uganda.

xii. Groat. L, Wang. D, (2002), Architectural research methods, Canada: John Wiley and Sons, Inc.

xiii. Holik. H, (2006), Handbook of paper and board, Weinheim: Wiley VCH Verlag GmbCH and co.

xiv. Kirwan. M. J, (2005), Paper and paperboard: Packaging technology, Oxford: Blackwell publishing Ltd.

xv. Lyons. A, (2007), Materials for Architects and Builders, 3rd Edition, Oxford: Butterworth and Heinemann publications

xvi. Maxwell. J.A, (2004), Qualitative research design: An interactive approach, 2nd Edition, Carlifornia: Sage publications.

xvii. Miles. B. M, Huberman. A. M, (1994), Qualitative data analysis: An expanded sourcebook, $2^{\text {nd }}$ Edition, Thousand Oaks, Carlifornia: Sage publications.

xviii. Ministry of Environment and Forests, (2011), Discussion paper on collection and recycling of waste paper in India, Ministry of Environment and Forests, Government of India.

xix. Miyake. R, (2009), Shigeru Ban: Paper in Architecture, Rizzoli International Publications.

xx. Ospina. S, (2004), Qualitative research, London: Sage publications.

xxi. Preston. S.J, Bank. L.C, (2011), Portals to an Architecture: Design of a temporary structure with paper tube arches, Madison: University of Wisconsin.

xxii. Schell. C, (1992), The value of case study as a research strategy, Manchester Business School.

xxiii. Schonwalder.J, (2008), Cardboard as a building material, Amsterdam: IOS press.

xxiv. Yin. R.K, (1984), Case Study Research: Design and Methods, Thousand Oaks, Carlifornia: Sage Publications.

xxv. Yin. R. K, (1994), Case Study Research: Design and Methods, 2nd Edition, Thousand Oaks, Carlifornia: Sage Publications.

xxvi. Yin. R. K, (2009), Case Study Research: Design and Methods, $4^{\text {th }}$ Edition, Thousand Oaks, Carlifornia: Sage Publications. 